\title{
Technology and Love for Everyone. Including the Elderly
}

\author{
Dora Ivonne Alvarez Tamayo* y Judith Cavazos Arroyo*
}

\begin{abstract}
Recepción: 27 de mayo de 2016
Aceptación: 20 de febrero de 2017

*Universidad Popular Autónoma del Estado de Puebla, México.

Correos electrónicos: doraivonne.alvarez@upaep.mx; judith.cavazos@upaep.mx

Se agradecen los comentarios de los árbitros de la revista.

(c) $\$=$

BY NC ND

Abstract. Technology for everyone is the trending goal. A quantitative study based on the Precaution Adoption Process Model and the theory of codes about everyone's free time management has been applied to the middle class elderly in Puebla, Mexico. This study reveals that their concept of free time does not reflect any connection with the use of technology, neither in the family, nor in friendship or leisure activities. However, a qualitative approach analyzing their discourse in social network, particularly Facebook, shows that technology has made an important contribution to diminish the distance among family, to stay updated, to rekindle friendships and to engage in a new relationship. Then the habits of the elderly in a virtual environment may be linked to an emotional factor.
\end{abstract}

Keywords: elderly people, componential analysis, social network, Peircean semiotics, habit.

\begin{abstract}
Tecnología y amor para todos. Incluso adultos mayores

Resumen. La tecnología al alcance de todos es un objetivo tendencia. Se aplica un estudio cuantitativo sobre el uso del tiempo libre basado en el Modelo de Adopción de la Precaución y la teoría del código en adultos mayores de clase media en Puebla, México. Se revela que el concepto que tienen de tiempo libre no refleja ninguna conexión con el uso de la tecnología, ni en lo familiar, la amistad o las actividades de ocio. Sin embargo, el análisis cualitativo de sus discursos en redes sociales, particularmente en Facebook, muestra que la tecnología contribuye a disminuir la distancia con su familia, a actualizarlos, al encuentro con amigos y a nuevas relaciones. Los hábitos de los adultos mayores en el entorno virtual están vinculados con la emoción.
\end{abstract}

Palabras clave: adultos mayores, análisis componencial, redes sociales, semiótica peirciana, hábito.

\section{Introduction}

Mexico has a population of more than 10 million elderly people, with an annual growth of $3.8 \%$. The projections indicate that the country is transforming itself, with a current life expectancy of 76.4 years (García \& Velarde, 2011), and the number of the elderly is expected to increase $21.1 \%$ by 2050 .

Puebla is a medium-sized city in which a large segment of the population in the late adulthood stage $(60+$ years old $)$ has more leisure time available than those in other stages of life. Statistics show that over $35 \%$ of older adults between 60 and
79 years are not formally employed, but engage in housework, less than 20\% are retired and another $20 \%$ continue to be employed (INSP, 2012).

With the objective of motivating senior citizens to be creative in their leisure time and to improve their social life by using social media, it is essential to understand their perceptions, intent, and practices pertaining to the use of social media in their spare time. This study focuses on middle class elderly people $(60+)$ in Puebla in order to identify the actions that they perform through virtual technology offered by social networks. 


\section{Interpreter profile}

Aging people (65 years and older) present signs of gradually declining physical health; in cognitive terms, most of them are mentally alert, and those who have some deterioration of memory and cognitive impairment are often able to compensate for this. Regarding psychosocial factors, many elderly people have lost close friends and relatives, and may think about their own death; they often question the meaning of life and require the support of family.

Retirement offers a scenario that provides new options for using their time, even finding new full- or part-time work. Adult learning may not be as fast or as obvious as child development, and involves both losses and gains; but contrary to popular opinion, the elderly can develop new skills (Papalia et al., 2009).

Specifically, in the state of Puebla, there are 514436 people who are 60 years old and older (INAPAM, 2014). A high percentage of this population is classified as active, although there is a prevalence of chronic diseases such as obesity, diabetes mellitus and hypertension.

With regard to family, most elderly people have adult sons and/or daughters and grandchildren. Some of them have stable relationships or are widowers. Their physical and mental condition leads them to wonder about the meaning of life and, even though they enjoy sharing time with family and friends, they claim their own space and independence.

With reference to the relationship between elderly people and social media, according to numbers offered by AMIPCI (2014), the use of the Internet by Mexican citizens has increased each year. In 2013, 51.2\% of the population were Internet users, of which $12 \%$ were 55 years or older. This reflects that the elderly recognize (maybe slowly) the new media as a reality reaching ever closer to their environment.

A research study profiling the Mexican context from a geriatric perspective, showed that family life and religious activities were the most frequent leisure pursuits, followed by relaxation, reading and watching television. Fewer activities such as going to the theater or cinema were reported (Guerrero et al., 2012).

Using new generation technology to communicate with each other is a challenge for the elderly because it requires using creative skills to incorporate the media into their current lifestyle, as well as learning and determination. According to Sternberg \& Kaufman (2012), creativity requires a confluence of six distinct but interrelated resources: intellectual abilities, knowledge, styles of thinking, personality, motivation, and environment. In this sense, when people are willing to put in up-front time to think in new ways, they can develop different options to connect with the people they care about. In the case of elderly people, creative thinkers recognize the importance of spending time to seek alternatives. Sometimes it is necessary for adults to restructure their strategies and modify their way of thinking to push their capacities in a new direction; these efforts may be trained and directed.

In this stage of life, the elderly have time to be aware of sensory, emotional and fun activities, and simple things can gain great meaning. Their mental processes tend to be creative and adaptive because they use their experience in creative and reflexive processes to gain wisdom (Butter \& Cols, 1998, quoted in Berger, 2009).

\section{Peirce's concept of habit}

Peirce, whose academic formation was in philosophy, showed a great deal of interest in the phenomena of signification and the inferential processes that allows it to be produced. One way to understand the different phenomena that present themselves to an individual (Peirce, 1974: CP. 1.23) is through three modes of existence: the qualitative positive possibility, called Firstness, the actual fact or act called Secondness; and the law that will govern the facts in the future, called Thirdness. It is within the Thirdness that habits belong.

Peirce explains that (1974: CP. 1.348) "each habit of an individual is a law; but these laws are modified so easily by the operation of self-control, that it is one of the most patent of facts that ideals and thought generally have a very great influence on human conduct".

The habit as a law helps the interpreter to decide the way to act. In this sense, Peirce explains that (1974: CP. 1.574):

Every action has a motive but an ideal only belongs to a line of conduct which is deliberate. To say that conduct is deliberate implies that each action, or each important action, is reviewed by the actor and that his judgment is passed upon it, as to whether he wishes his future conduct to be like that or not. [...] His self-criticism followed by a more or less conscious resolution that in its turn excites a determination of his habit, will, modify a future action; but it will not generally be a moving cause to action. It is an almost purely passive liking for a way of doing whatever he may be moved to do. Although it affects his own conduct, and nobody else's yet the quality of feeling (for it is merely a quality of feeling) is just the same, whether his own conduct or that of another person, real or imaginary, is the object of the feeling.

A sign takes the place of the object (located in Secondness), which can be a material or immaterial entity, perceivable or 
imaginable; this object has its basis in fact, and represents an encounter with the experience or update of the event. Finally, the interpretant (located in Thirdness) (Peirce, 1974: CP. 2.234), refers to the relations of thought that allow the production of a law. The interpretant presumes the triadic and intelligent action of the sign in the mind of an interpreter (Peirce, 1974: CP. 5.472). For Peirce, the recognizing of a belief is a judgment, and "a belief is an intelligent habit upon which we shall act when occasion presents itself" (Peirce, 1974: CP. 2.435).

\section{The theory of codes for componential analysis}

The theory of codes developed by Eco (2005) was selected to understand the sharing codes for a social group and to identify denotations and connotations related to the semantic field. This theory provides a componential scheme that considers the structure of a sign as a cultural unit.

Eco (2005) explains that semiotics is concerned with signs as social forces, that is, social life is developed based not on things but in cultural units. Within a social group, these cultural units, formed by expression and content, which could be denotations and connotations, constitute conventional systems called codes along with structures and rules.

Signification and application are substitute terms for connotation and denotation. The application of terms is the collection of objects to which they refer, and the signification refers to all the qualities that are indicated for it (Peirce, 1974: CP 2.431).

Following Peirce (1974, CP. 2.643), "the belief of a rule is a habit". The belief is settled in the interpreter's mind and affects the way he or she acts. Peirce emphasizes that (Peirce, 1974: CP. 2.148) "a genuine belief, or opinion is something on which a man is prepared to act, and it is therefore, in a general sense, a habit and every habit is a general law". This law prepares the elderly to take action in a determined context and situation.

\section{Precaution Adoption Process Model}

The Precaution Adoption Process Model (PAPM) identifies seven gradual stages that lead step by step from how a person makes a decision to turning it into an action. Janis \& Mann (1997) explain the responses to threats by proposing categories of people's beliefs about their ability to face the threats. Then Weinstein \& Sandman (1992) identify seven stages along the path from the lack of awareness to action. In short the steps are: a) Step 1. People are not aware of the social problem (topic). The person does not recognize the importance of the situation and he/she is unprepared and uninformed about it.

b) Step 2. The person learns something about the subject, but still does not generate any commitment. Then, a risk is recognized, but no action is performed because it is not perceived as vulnerable or is not interested in change.

c) Step 3. People who reach this stage are considering a response to make a decision, but are still undecided.

d) Step 4. The Precaution Adoption Process stops, deciding not to act, at least for now. If the person chooses not to act, then it is at this stage that he/she could suffer a relapse.

e) Step 5. The individual decides to act and takes the precaution, which involves performing an action plan in which he/she evaluates when and how the behavior will be issued.

f) Step 6. This step involves moving from intention to action behavior, so the real change begins. Work should be focused on self-control and management of relapses.

$g$ ) Step 7. Finally, maintenance is generated over time.

\section{Methodology}

Some advantages distinguish the PAPM from other theories of behavior change; a) it includes a stage that comprises the lack of awareness of an issue, making a progress of awareness, engagement, action and maintenance (Chapin, 2016), and $b)$ it is possible to combine the PAPM with other theories to facilitate comprehension of a behavior (Walsh et al., 2007). In this sense, semiotics as a research method allows understanding the systems and sub-systems that function as a basis of meaning, thinking and action determining the human behavior. Particularly, in the case of the theory of code by Umberto Eco (2005), if the axiom of human communication that states the impossibility of not communicating -behavior as synonym of communication- (Watzlawick et al., 1985), the code, as a system of conventional signs, makes easy the comprehension of the communication possibilities between members of a social group (Eco, 2005). Thus, the code offers the opportunity to analyze the predisposition to the use of leisure time in elderly.

A convergent parallel mixed method (Creswell, 2014) was designed in order to integrate the information that allows us to identify the activities of elderly people on social media, verify if they are conscious that the attention that they pay to these activities, is a creative use of leisure time, and identify the kind of interactions that they have (if they occur) so as to recognize the topics of their interests and effects. The quantitative and qualitative data were compared to see 
if they were consistent or if there were a contradiction or a lack of information.

The starting point was the quantitative study, based on the Precaution Adoption Process Model about leisure time management, which was oriented to the elder people in Puebla, Mexico. A descriptive and cross-sectional study was developed and applied to 235 respondents that belong to the middle class. The interview characteristics showed that $45.7 \%$ were male and $54.3 \%$ female. Also, $53.6 \%$ were between 60 and 69 years old, 32.8\% between 70 and 79 and $13.6 \%$ between 80 and 88 years old.

The second part was a qualitative exercise based on nonparticipative observation, which consisted in "tracking" eleven Facebook users who lived in Puebla and were in the range of 60-80 years old. The analysis of the discourse was developed from a semiotic perspective based on Peirce's trichotomies, and applying a componential analysis considering the theory of codes by Eco. Lastly, the results of both studies were compared.

\section{Comparative analysis}

\section{1. Quantitative data}

The cross-tabulation analysis showed that for age and gender there were no significant differences in practices and time spent on leisure activities. However, meaningful differences by gender were found related to self-efficacy: Women are more persistent than men in achieving goals $(p=0.009)$, have more confidence in handling unexpected events ( $p=$ 0.033 ) and have better management of skills and resources in unexpected situations $(p=0.008)$.

This study revealed that the majority of respondents agreed (47.2\%) about using their leisure time in activities that encou-

Graph 1. Activities that elderly people preferred.

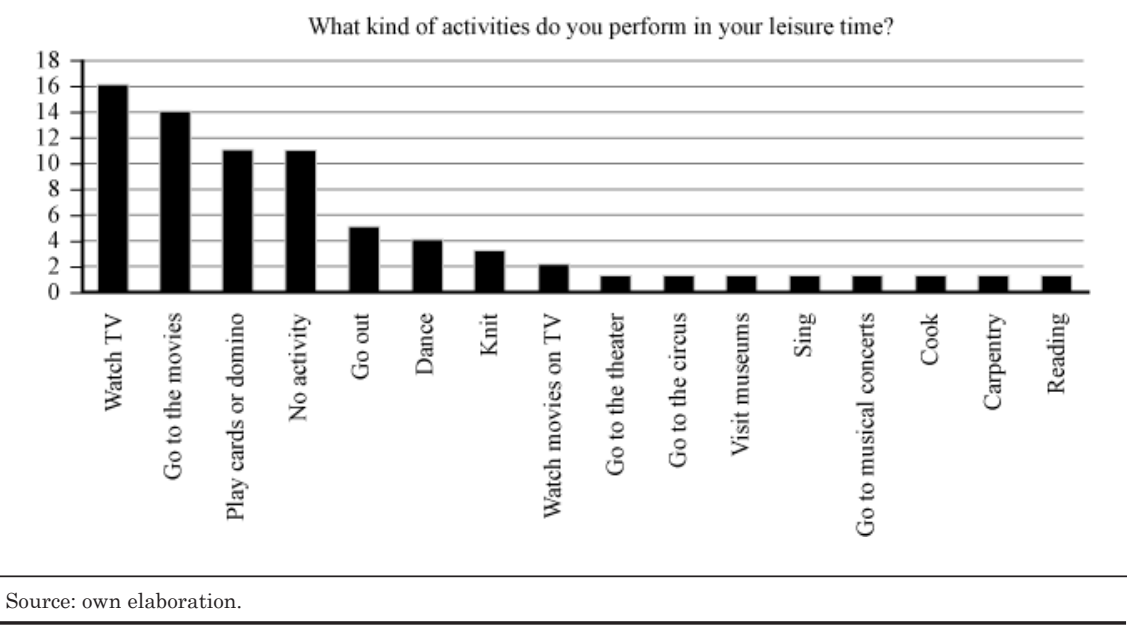

rage creativity, but the respondents were distributed in: Stage 5 , decided to act because action offers distraction, improved mood, improved mental alertness and human relationships, Stage 2, unengaged and Stage 3, undecided whether to act (graph 1).

With regard to the componential analysis, when respondents were asked about what activities they did in their leisure time, they never mentioned the use of media technology, but the qualitative study reflected a different situation. This means there was no trace in the denotation nor in connotation that demonstrated consciousness of this activity and the time that they spent on it (graph 1).

A second question was designed to identify the link between leisure time and the use of social network. The link is not evident, but the answers suggest preferences about the activities that they enjoy. From their responses, it appears that older adults like to perform activities with people they care about (sons and daughters, grandchildren, siblings and friends).

\section{2. Qualitative data}

Eleven elderly people were tracked on Facebook for two weeks. All of them had had at least a high school education. More than 50\% were employed during their working life, $60 \%$ did not perform working activities and 40\% actually worked in an academic environment; this characteristic could be a facilitator for using media technology. The average of "friends" accepted was 298; the smallest number of friends was 39 and the largest was 1030.

Following the universal categories of Peirce, the phenomenon is explained in the following manner:

Social networks offer the possibility of interaction through a digital environment. Firstness, this category included the digital devices, the possibility to activate links with other people and the motivation to use the new resources. At Secondness, it is possible to identify that people had previously established relationships and Facebook functioned as a meeting point where elderly people participated in communities encouraging these relationships. Some interpreters used Facebook to avoid feelings of loneliness or boredom.

With regard to the habits, in Thirdness we observed that elderly people used Facebook to keep in touch with people they knew before, to try new experiences, to create new relationships, to expand their presence, and 
to share their points of view, pleasures and hobbies. The observations demonstrated that the individuals included in the sample had a strong preference to share pictures about their family and themselves. They were very careful with the pictures they placed in their profiles. They appear smiling, enjoying their hobbies or sometimes using metonymies as a sign of themselves. For example, if someone loved to play the guitar, the person appeared in the profile playing a guitar or used a picture of a guitar as their profile picture. The elderly have discovered that they can establish contact with known or unknown people to fill the void (figure 1).

\section{Findings and discussion}

In Puebla, Mexico, the quantitative study revealed that the interpreters did not link the "free time" concept with the use of technology in the family, social or leisure activities. However, the qualitative approach showed that technology had taken on an important function of diminishing the distance with their families, staying informed, reconnecting with friends from the past and even developing new couple relationships. This means that the elderly people in the City of Puebla did not categorize the use of social networks as a leisure activity, but as a communication activity. The individuals perceived media technology as a challenge and an opportunity; however, they did not realize their creative aspect.

The topics that the elderly shared on Facebook were: family and values, religion, politics in an ironic or subversive tone, and humor. Their motivation to use social network was related to their necessity to lessen the distance between them and their loved ones and strengthen relationships, to express thoughts and feelings, to rediscover or reconnect with people from the past and to have fun. The respondents were classified in relation to the Precaution Adoption Process Model stages. Each stage represents the disposition to the change in behavior.

\section{Conclusions}

When the comprehension of the topic and environment is controversial, the gathering of data opens the possibility for an argumentative debate with different scenarios. The preparation of plausible arguments depends on the data. But qualitative and quantitative methods offer different results that can be contrasted. In our case of study, the quantitative data did not reflect the use of social media in the scheme of leisure time for the elderly that belong to middle class in the context we investigated.

Relationships are the result of communication interactions; in this sense, new media and social networks provide a different scenario to establish interactions and create new relationships or maintain those previously established. Even though physical distance is avoided as a barrier in human relationships, humans need sensory contact and physical presence. However, digital media tries to supply the lack of physical presence through a variety of resources to produce signs (emoticons, voice recordings, photos and video streaming).

Furthermore, the elderly people need to learn how to use new media. This has become a necessity to avoid the gap between grandparents and grandchildren. The interpreters are not conscious of the requirements of creativity that such activity represents. Nevertheless, the qualitative data offers information about how the elderly incorporate social network as a frequent activity and allows identifying the kind of interactions they have, highlighting their personal relationships as a motivation to act. According to Saiz (2012), if the emotion is understood as a source of habits, then the practices of the elderly in virtual environments are linked with an emotional factor intrinsically related to those people with whom they keep in contact and who motivate them to approach to technology. In this sense, technology represents an opportunity to create new links with their meaningful world.
Figure 1. Phenomenon analysis.

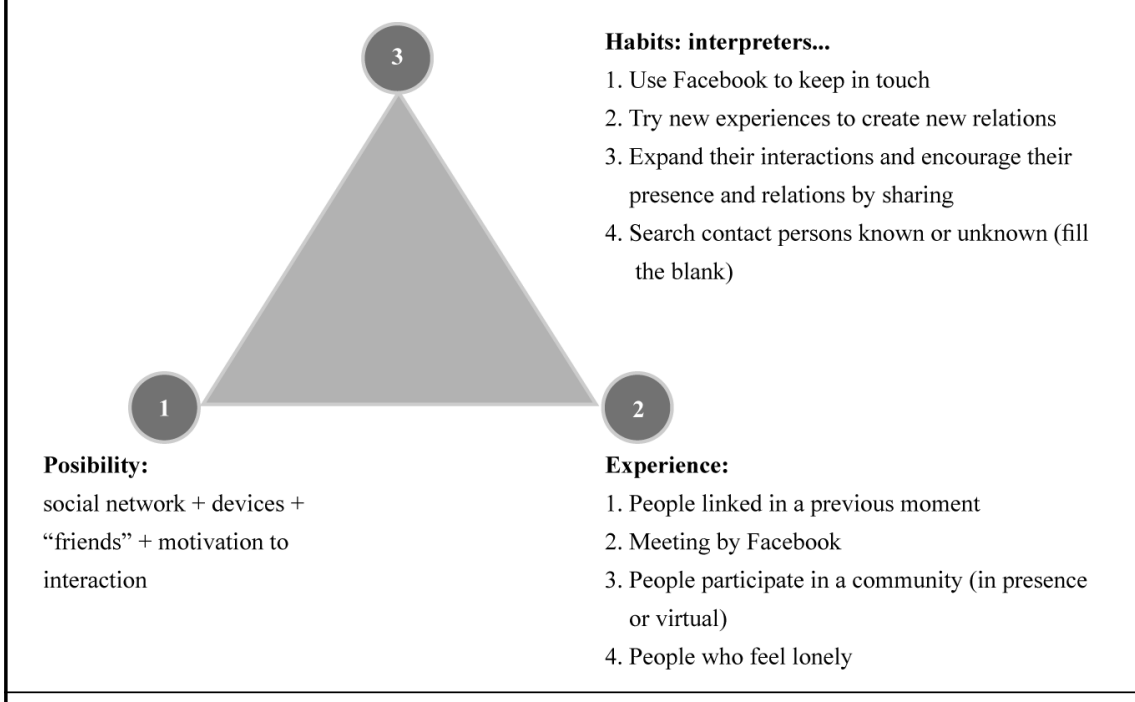

Source: own elaboration 


\section{Prospective analysis}

The results suggest the need to promote the use of social media among elderly in order to avoid the loneliness and boredom and stimulate the creativity in their current lifestyle. One of the most relevant challenges is the development of skills for using the new media. One way to diminish the perceived risk is showing the benefits and the usability of new technologies. For the future, this involves the development of user-centric strategies to facilitate the learning process, reduce the perceived risk through awareness of benefits and promote the closeness to their loved ones using technology.

Social environment is crucial because it supports the learning process. In this case, young expert users help rookie older users. This represents a need and an opportunity that society has to assume to improve the quality of life, coexistence and the reduction of the digital gap. If children teach parents to use technology, then grandchildren could teach grandparents. These kind of interactions not only have pragmatic goals but also social purposes because they strengthen family ties.

Acceptance and adoption of technology have implications in a communication context. These include learning technical codes and languages of digital media and the construction of shared fields that enables the incorporation of new concepts. Whenever the code offers the possibility to share positive experiences between generations as a learning strategy. New studies could be developed with regard to elderly behavior change, code-technology relationships as well as habits and creativity in leisure time.

References

AMIPCI (Asociación Mexicana de Internet).

(2014). Estudio sobre los hábitos de los usuarios de internet en México 2014.

Retrieved from https://www.asociaciondeinternet.mx/es/estudios

Berger, K. (2009). Psicología del desarrollo: adulter.y vejez. Madrid: Editorial Médica Panamericana.

Creswell, J. (2014). Research design. Qualitative, quantitative and mixed methods approaches (4th ed.). Los Angeles: Sage.

Chapin, J. (2016). Adolescents and cyber bullying: The Precaution Adoption Process Model. Education and Information Technologies, 21(4), 719-728.

Eco, U. (2005). La estructura ausente. Introducción a la semiótica. México: De Bolsillo.

García, V., \& Velarde, S. (2011). Ajuste en la estructura por edad de las poblaciones censales en México. Consejo Nacional de Población, 1-32. Retrieved from http://www.conapo.gob.mx/es/ CONAPO/Ajuste_en_la_estructura_por_edad_ de_las_poblaciones_censales_de_Mexico
Guerrero, R., Quevedo, E., García, R., \& Zavala, M. (2012). Perfil gerontológico del adulto mayor en Tabasco. Revista de Salud Pública, 14(1), 88-101.

Janis, I., \& Mann, L. (1977). Decision Making: A psychological analysis of conflict, choice, and commitment. New York: Free Press.

INAPAm (Instituto Nacional de las Personas Adultas Mayores). (2014). Servicios. Retrieved from http://www.inapam.gob. $\mathrm{mx} / \mathrm{es} /$ inapam/Puebla

INSP (Instituto Nacional de la Salud Pública). (2012). Encuesta Nacional de Salud y Nutrición 2012. México: INSP.

Papalia, D., Sterns, H., Feldman, R., \& Camp, C. (2009). Desarrollo del adulto y vejez. México: McGraw-Hill Interamericana.

Peirce, C. (1974). Collected Papers of Charles Sanders Peirce. C. Hartshorne, P. Weiss (Eds.) (Vols. 1-6) \& A. Burks (Vols. 7-8). Cambridge MA: The Blecknap Press of Harvard University Press.
Saiz, V. (2012). Disposiciones afectivas y cambio social. CIC Cuadernos de Información y Comunicación, 17, 107-133 Retrieved from http://revistas.ucm. es/index.php/CIYC/article/viewFile/39260/37843

Sternberg, R., \& Kaufman, J. (2012). When your race is almost run, but you feel you're not yet done: Application of the propulsion theory of creative contributions to late-career challenges. Journal of Creative Behavior, 6(1), 66-76.

Walsh, S., Dignan, M., \& Caldwell, G. (2007). The PAPM, diffusion theory, and violent death surveillance. American Journal of Health Behavior, 31(5), 451-461.

Watzlawick, P., Helmick, B., \& Jackson, D. (1985). Teoría de la comunicación bumana. Barcelona: Herder.

Weinstein, N., \& Sandman, P. (1992). A Model of the Precaution Adoption Process: Evidence from home radon testing. Health Psychology, 11, 170-180. 